菅泰 雄** 高原耕 作 ${ }^{* * *}$ 池田泉 広 ${ }^{\dagger}$

\title{
Recognition of Weld Line and Automatic Weld Line Tracking by Welding Robot with Visual and Arc Voltage Sensing System
}

Yasuo SUGA, Kosaku TAKAHARA and Motohiro IKEDA

\begin{abstract}
In automatic welding of thin steel plates, it is difficult to detect weld line by visual sensor, because the weld line is finer and the surface tends to reflect images of arcs and surrounding apparatus. Moreover, it is important to keep the optimum arc length in welding of thin plates. Therefore, a basic welding arc robot system with a visual sensor and an arc voltage sensor controlled by personal computers was constructed, and effects of lighting methods on detection of the weld line and the effectiveness of these control systems were experimentally investigated. As the result, it was made clear that reflection lighting method is more useful than the other conventional lighting methods for the recognition of the weld line and control systems constructed are effective for automatic welding of thin steel plates.

Key words : visual sensing system, automatic tracking, arc length control system, welding robot, in-process control, lighting method
\end{abstract}

\section{1. 緒 言}

生産の自動化に伴って溶接ロボットが急速に普及し ている、しかし, 溶接ロボットの少量生産品や精密部 品への適用の拡大に伴って, 従来のティーチングプレ イバック方式ではこれに十分対応できないとの認識が 高まっている，このため，より高精度で柔軟性の高い 溶接システムを目指して，センサを有する知能ロボッ トの研究が行われており，アークセンシングや視覚セ ンシングによる溶接線の検出や開先形状の認識等の研 究が各方面で進められている 11-31. 一方, 薄板の突 合せ溶接では，一般にI 形開先が用いられるためア一 クセンシングの適用は困難であり，また左右の材料を 完全に密着させるため溶接線が細く, 視覚センサによ るその検出も比較的むずかし(4)51。このため, 溶接 線の認識率向上を目的とした画像処理等の研究が行わ れつつあり効果を上げているが, 薄板溶接に対しては 必ずしも十分ではなく，広く実用に供される段階には 至っていない。そこで, パーソナルコンピュータによ る基本的なアーク溶接ロボットシステムを構築し, 視

* 原稿受付 平成 2年11月14日. 1990年度精密工 学会春季大会学術講演会 (平成 2年3月28日)に て発表

** 正会貝 慶応義塾大学理工学部（横浜市港北 区日吉3-14-1)

*** 正 会 員 マツダ(侏)（広島県安芸郡府中町新地 3-1)

†慶応義塾大学大学院
覚センシングに基本的に重要と思われる照明と溶接線 の画像との関係について実験を行い, 視覚センシング による薄板溶接における溶接線認識と追従制御の可能 性について検討した。 また, 薄板の溶接における重要 なパラメータの一つであるアーク長をアーク電圧セン サによって制御するためのシステムを構築しその有効 性について検討を加えた。

\section{2. システム機器の概略}

図1 は、パーソナルコンピュー夕を用いた基本的な アーク溶接ロボットシステムの機器構成を示す. 装置 は，大別して視覚センサにより溶接線を認識して溶接 トーチをそれに追従させるためのシステム, 及びアー ク電圧を測定し, トーチを上下に移動してアーク長を

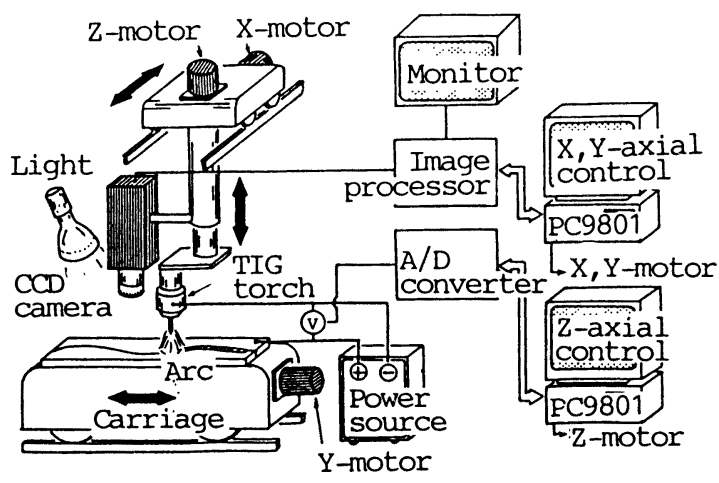

Fig. 1 system of welding robot 


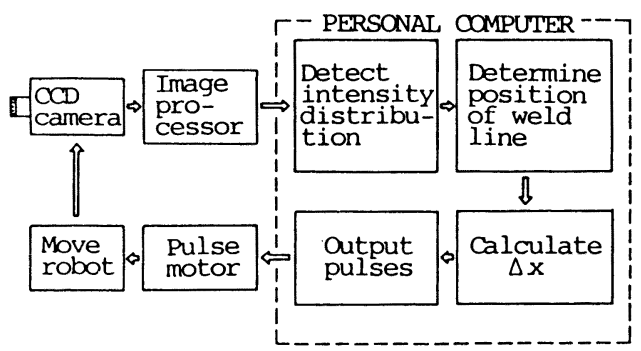

Fig. 2 Recognition and tracking system of weld line

制御するためのシステムから構成されている。すなわ ち, X, Y, Z の 3 軸方向に駆動可能な直角座標口ボ ッ, TIG 溶接装置, CCD カメラ, 画像処理装置, モ ニタテレビ, A/D コンバータ及び制御用の16ビットの パーソナルコンピュータ（日本電気製，PC9801）等か ら成る。なお，溶接線の追従システムとアーク長制御 システムを本コンピュータ1台で制御するには，性能 的に負担が過大であると判断されたため，本システム では 2 台のコンピュータによってそれぞれ独立に制御 している、ロボットは 3 自由度であり，X軸，Y軸を 駆動することにより溶接線の追従制御を，Z軸を駆動 することによりアーク長制御を実現している.

\section{3. 溶接線の認識と追従}

\section{1 認識と追従システム}

四2 に，溶接線を認識し，溶接卜一チをそれに追従 させるためのシステムの概略を示す，溶接線及びその 近傍の画像はCCD カメラによって収録される。画像デ 一夕は画像処理装置によって64段階のディジタル数値 として画像メモリー $(256 \times 256,8$ bit $)$ に記録される. 1 画面 ( 1 フレーム) の撮影には $1 / 30 \mathrm{~s}$ を要する.コ ンピュータに取り込まれた画像データのうち, 任意の 1 本の走査線 (本実験では, 画面の中央すなわち上か ら128 本目）についてその輝度分布（64階調）を検出 し, 輝度の特異な点（例えば、最も輝度の低い点 $\mathrm{P}$ 。 あるいは高い点 $\mathrm{P}_{p}$ ）の座標を求めておき,これを溶 接線の位置の検出に利用する.なお, 本実験では主と して輝度の低い点 $\mathrm{P}_{\mathrm{b}}$ を溶接線の検出に用いている.

以上の手順で認識された溶接線の位置座標とそのと きの溶接トーチの位置座標よりそれらの差異を計算し, パルスモータを駆動することにより溶接線の追従を行 う。追従実験を行うにあたっては，簡単のためY軸方 向の移動速度を一定とし，X軸のみを制御して追従を 実現している。困3 は溶接線追従のためのX軸制御用 のフローチャートであり, 図4 は追従制御の原理を示 す模式図である。困中 $\mathrm{k}$ は 1 画素に相当する距離に対 応するモータの出力パルス数 (pulses/pixel) である.

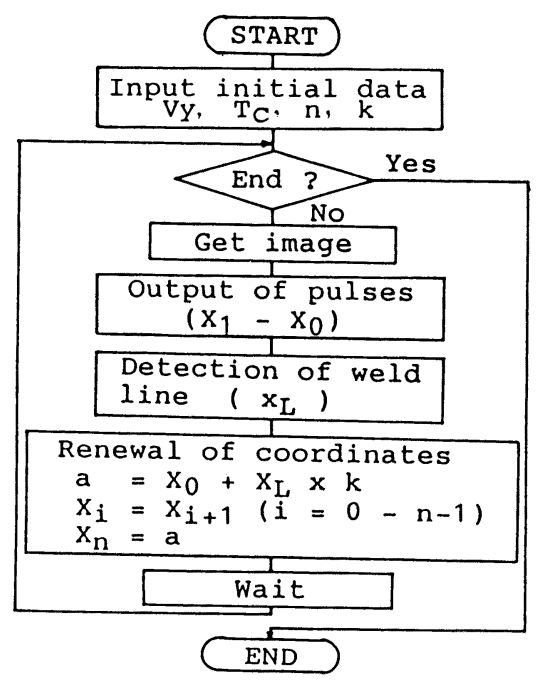

Fig. 3 Flow chart of $\mathrm{X}$-axial control

溶接を開始するに当たっては，溶接速度 V、，1制御 周期（サイクルタイム） $T_{0}$, 溶接線の認識方法（走 查線上の輝点または暗点のどちらを検出し溶接線とし て認識するか）等の指示を与えておく.

溶接線の位置が検出されると, 以下の順序でその追 従が行われる.四4において，XＯYは絶対（固定） 座標を, x O y はCCDカメラと共にY方向に定速度 V、 で移動する相対（移動）座標を示している.トーチの 現在位置座標を $X_{\text {。 }}$ とすると $\mathrm{i}$ 制御周期後に溶接すべ きX座標はXi で示される. また, 現在のカメラの視 野内における溶接線検出点の $\mathrm{x}$ 座標を $\mathrm{x}_{\mathrm{L}}$ とすると, この位置の座標 $\mathrm{X}_{\mathrm{n}}$ は, $\mathrm{X}_{\mathrm{n}}=\mathrm{X}_{\oslash}+\mathrm{x}_{\llcorner}$となり, $\mathrm{n}$ 制

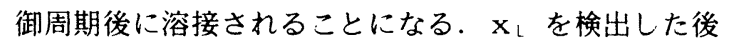

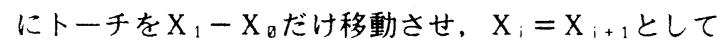
座標を更新し, 次の制御周期まで待機する。これを絽 り返すことにより、トーチは溶接線に追従する．本シ

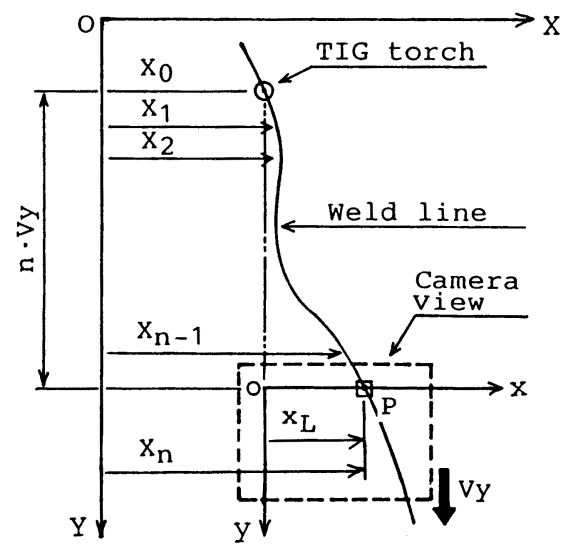

Fig. 4 Principle of automatic 


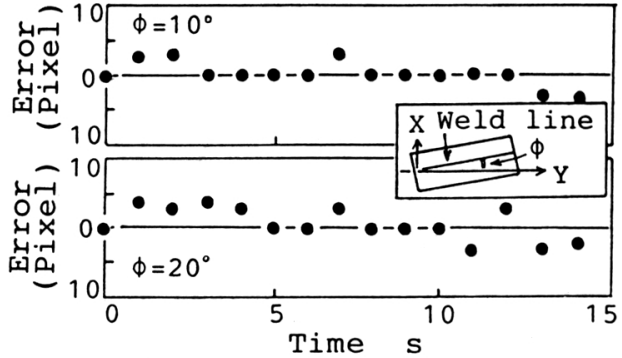

Fig.5 Error in tracking of angled

ステムでは， 1 制御周期を $0.5 \mathrm{~s}$ に設定している。 な お,プログラムには C 言語 (MS-C) を使用した.

図5に，溶接線とロボットのY 軸とのなす角度 $\phi$ を $10^{\circ}$ および $20^{\circ}$ に設定して, 溶接卜一千先端を溶接線 に追従させた場合の追従誤差の測定結果を示す. 図中, 誤差は画素数で測定し表示してある. 図より，傾き角 度 $\phi$ が $20^{\circ}$ 以下であれば追従誤差は概略 \pm 4 pixel以下 であることがわかる. カメラの視野の幅を $25.6 \mathrm{~mm} に$ 設 定すると, 1 pixel は母材表面上で0.1mmに相当し,し たがって追従誤差は $00.4 \mathrm{~mm}$ 以下であり, 本システム が溶接線追従制御に有効であることが確認される.

\section{2 認識に及ぼす照明の影響}

溶接線を正確にかつ安定して認識するためには，適 切な照明が行われなければならない，そこで，まず溶 接線の認識に及ぼす照明の影響について検討した。

図6は，本実験で採用した 3 種類の照明方法を模式 的に示したものである. 本実験では, 照明用光源とし て, 市販の白熱電球（ $60 \mathrm{~W}$ ，つや消し）を用いてい る. 図中，(a) は溶接線に対して直角方向 (横方向) か ら照明した場合で, CCD カメラは母材に対して垂直に 設置してある. 照明は主として両側から行っているが, 片側照明についても検討している．（b）は溶接方向前 方から照明した場合である。(a) (b)のいずれについて も, 照明角度 $\alpha$ は, $30^{\circ}$ から $75^{\circ}$ まで変化させて検討 した. (c) は, 照明用の光源を鏡面の母材表面に反射 させ，その反射光を直接 $\mathrm{CCD} メ ラ の$ 視野内に導入す る方式であり, 照明角度 $\alpha$ とカメラの角度 $\beta$ が等しく なるように光源とカメラが配置されている. 光源の光

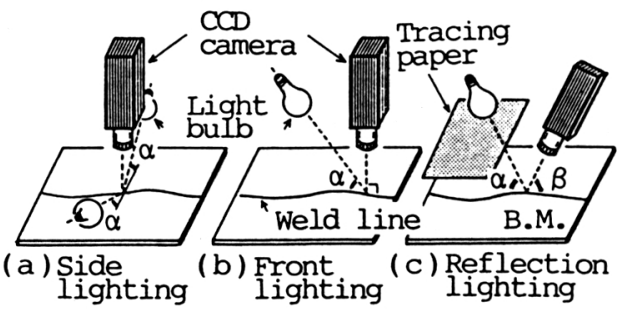
Fig. 6 Lighting for recognition of

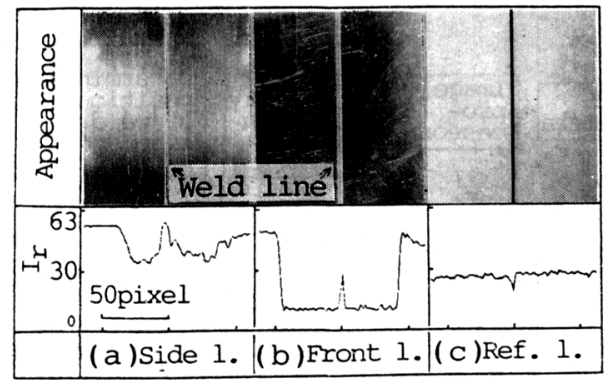

Fig. 7 Effect of lighting on brightnition of weld line (sUS304)

を拡散させてその強度分布を均一化するため, 電球の 下部を半透明材料(トレーシングペーパ)で覆っている

(以後, 簡単のため(a) を側方照明, Side lighting, (b) を前方照明, Front lighting, (c) を反射照明, Reflection lighting と称する. )

上記 3 種類の照明法を用い，板厚 $0.5 \mathrm{~mm}$ のステンレ 又鋼板の突合せ部をカメラで撮影した場合の溶接線及 びその近傍の外観写真, 並びに CCDカメラで撮影した 画像の画面中央における走査線上の輝度分布を図7に 示す.なお, 図中の外観写真撮影には一眼レフカメラ を用い, 輝度分布は CCDカメラで撮像したデー夕によ るものであるため, 両者は厳密には対応していない， 試験片の切断面は, シェアリングで切断した後, フラ イス盤で仕上げてある. 左右の母材は接触させてある が, 母材端面の凹凸が原因で, 実際には0.1〜0.2mm程 度の間隙が形成されている.

図より，(a)の側方照明及び (b) の前方照明（いずれ も $\left.\alpha=60^{\circ}\right)$ では，いずれも母材エッジ部が輝いてお り，溶接線は明るい線として観察される，その輝度は 母材部のそれより高くなる傾向があり，これを利用し て走査線上で最も輝度の高い点を溶接線として認識す るという方法も考えられる。しかし，側方照明 (a) で は母材の一部の輝度が上昇して溶接線の輝度を超える 場合があった．また，前方照明（b) では，鏡面状態の 母材表面にカメラの黒い本体や一部の金属部が写り, その輝度分布が必ずしも均一とはならない。この場合 カメラを黒い容器で覆うなどの適当な手段を講じれば 溶接線認識に適用できる可能性はあるが, 後に述べる ようにアーク光の悪影響を受けやすい。したがって， 側方及び前方照明は溶接線の認識に適しているとは考 え難い，これに対し，反射照明(c) では均一な光源を 母材表面で反射させるため, 輝度分布が概略均一とな り，溶接線は常に高輝度の母材表面を背景に輝度の低 い線として観察される. その結果, 溶接線は走査線上 で最も輝度の低い点として安定して認識できる.

図8は，SPCC鋼板の溶接線認識におよほす照明法の 影響を比較したものである．側方照明 (a) では母材端 


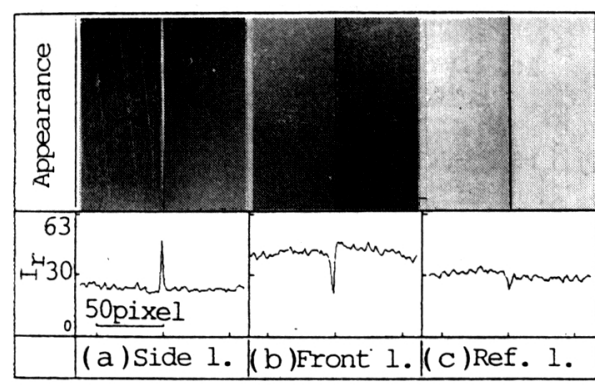

Fig. 8 Effect of lighting on brightness distribution and recog-

部のエッジが輝く場合とそうでない場合があり，安定 した認識が困難であった．前方照明(b) では，ステン レス鋼の場合と異なり，表面が鏡面を呈していないた め母材表面の輝度分布が比較的均一であり, かつ母材 エッジ部が輝くことがないため, 溶接線を輝度の最も 低い点として安定して認識することが可能であった。

（c）の反射照明では，ステンレス鋼の場合と同様，母 材表面はほぼ均一な輝度分布を呈しており, 溶接線は 暗い線として観察される。したがって，走査線上で最 も輝度の低い点として認識が可能である.

図7及び8より，反射照明を用いれば材料の表面状態 に関係せず溶接線を認識できる可能性が示された。し かし, 母材の輝度と溶接線の輝度との差が小さく, 誤 認識の恐れがあった。これは照明の輝度が低いためで， この点と実用性とを考慮して，図9 中に示す反射照明 法を提案する.これは, 電球を所定の形状（たとえば 円形）の容器に納め, その下部に光を拡散して広い面 光源とするための半透明材料（拡散板）を取り付けた 光源を用い, この面光源の母材表面への映り込み像を 溶接線と共にカメラにとらえる方法である. 図中 (a), (b) は，それぞれステンレス鋼及びSPCC鋼に本照明法 を適用した場合の結果を示している.いずれも, 光源 内の母材の輝度分布はほぼ均一である. また容器内の 電球の光が有効に照明に利用されているため, $60 \mathrm{~W} の$ 電球であっても母材の輝度が比較的高い. その結果, 図7.8 の反射照明に比べて母材と溶接線との輝度の差 が大きくなっており, 本照明法を用いることによって

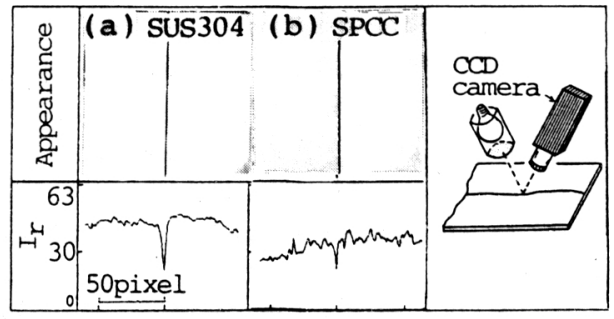

Fig.9 Recognition of weld line by reflection lighting

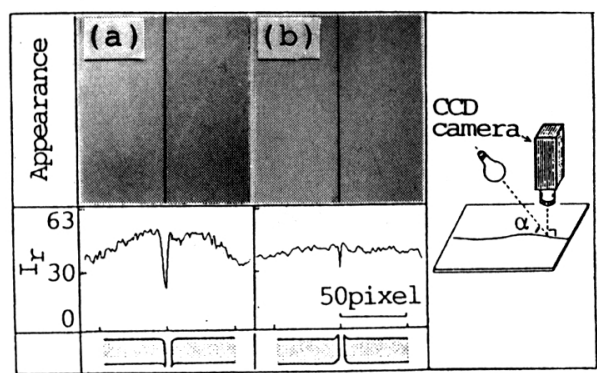

Fig.10 Effect of edge shape on

安定した溶接線の認識が可能であることがわかる.

図10は, 溶接線認識に及ぼす母材切断面の影響を示 したもので，一例として前方照明によるSPCC鋼の溶接 線の認識結果を示している. 薄板のせん断による切断 では，端部に若千のだれが生じる．困より，だれが下 方にある (a) では, 開先幅の増大と同様の効果があり， 溶接線の認識は容易となる。逆に，だれが上方にある 場合 (b) では, 開先巾の減少と同様の効果が生ずる. なお，Fig.8 (b) に示したように，切断面を機械加工し た場合はこれらの中間的な傾向を示している.

表1 は, 以上の実験を種々の照明条件に対して行っ た結果をまとめたものである. 照明方法としては, 側 方照明（両側, 片側）, 前方照明（いずれも照明角度 $\left.\alpha=45,60,75^{\circ}\right)$ 及び反射照明（ $\alpha=\beta=75^{\circ} ） に$ ついて，また母材端部の状態については，機械仕上げ， せん断加工によるだれが下方及び上方にある場合の 3 種類について検討した. 表中, 溶接線の認識の難易度

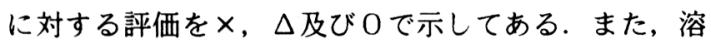
接線の認識が困難な理由として, 母材端部が輝くこと がある場合を記号 Aで，母材の輝度分布が均一ではな い場合を記号 Bで，母材表面に像が写る場合を記号 C で示してある.一般に，表面が鏡面であるステンレス 鋼板においては, 側方および前方照明では母材エッジ 部が輝き,また母材表面に周囲の像が写るため誤認識 を生じやすい．また照明の角度 $\alpha$ が $60^{\circ}$ を超えると光 源の反射光の一部が視野に入り母材の輝度分布が不均 Table 1 Effect of lighting method on recognition of weld line

\begin{tabular}{|c|c|c|c|c|c|c|c|c|c|}
\hline \multirow{2}{*}{\multicolumn{4}{|c|}{ Lighting }} & \multicolumn{6}{|c|}{ Base metal } \\
\hline & & & & \multicolumn{3}{|c|}{ SPCC } & \multicolumn{3}{|c|}{ SUS304 } \\
\hline \multirow{3}{*}{ - } & \multicolumn{3}{|c|}{$\left|\alpha\left(^{\circ}\right)\right| \beta\left(^{\circ}\right)$} & $x_{1}$ & $\bar{z}$ & 1 & 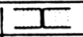 & $\sqrt{1}$ & 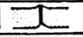 \\
\hline & 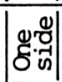 & $\begin{array}{l}45 \\
60 \\
75\end{array}$ & $\begin{array}{l}90 \\
90 \\
90\end{array}$ & \begin{tabular}{ll|}
$\times$ & $\mathrm{A}$ \\
$\times$ & $\mathrm{A}$ \\
$\times$ & $\mathrm{AB}$
\end{tabular} & $\left|\begin{array}{ll|}x & A \\
\times & A \\
\times & A B\end{array}\right|$ & $\begin{array}{l}\Delta \\
\Delta \\
\times \text { B }\end{array}$ & $\begin{array}{ll}\times & A C \\
\times & A C \\
\times & A B C\end{array}$ & $\begin{array}{ll}\times & \mathrm{AC} \\
\times & \mathrm{AC} \\
\times & \mathrm{ABC}\end{array}$ & $\begin{array}{l}\times A C \\
\times A C \\
\times A B C\end{array}$ \\
\hline & $\mid$\begin{tabular}{|l|}
5.8 \\
8.7 \\
0
\end{tabular} & \begin{tabular}{|l}
45 \\
60 \\
75
\end{tabular} & $\begin{array}{l}90 \\
90 \\
90\end{array}$ & $\begin{array}{ll}\times & A \\
\times & A \\
\times & A B\end{array}$ & $\left|\begin{array}{ll}\times & \mathrm{A} \\
\times & \mathrm{A} \\
\times & \mathrm{AB}\end{array}\right|$ & $\Delta_{\Delta}^{\Delta}$ & $\begin{array}{ll}\times & A C \\
\times & A C \\
\times & A B C\end{array}$ & $\mid \begin{array}{ll}\times & \mathrm{AC} \\
\times & \mathrm{AC} \\
\times & \mathrm{ABC}\end{array}$ & $\mid \begin{array}{ll}\times & \mathrm{AC} \\
\times & \mathrm{AC} \\
\times & \mathrm{ABC}\end{array}$ \\
\hline & & $\begin{array}{l}45 \\
60 \\
75\end{array}$ & $\begin{array}{l}90 \\
90 \\
90 \\
\end{array}$ & $\begin{array}{l}\Delta_{\Delta} \\
\Delta_{\mathrm{B}}\end{array}$ & $\begin{array}{l}\Delta \\
\Delta \\
\Delta_{B}\end{array}$ & $\begin{array}{l}\Delta \\
\Delta \\
\Delta B\end{array}$ & $\mid \begin{array}{ll}\times & \mathrm{C} \\
\times & \mathrm{C} \\
\times & \mathrm{BC}\end{array}$ & \begin{tabular}{|ll}
$\times$ & $\mathrm{C}$ \\
$\times$ & $\mathrm{C}$ \\
$\times$ & $\mathrm{BC}$ \\
\end{tabular} & $\mid \begin{array}{ll}\times & C \\
\times & C \\
\times & B C \\
\end{array}$ \\
\hline & 1. & 75 & 75 & $\mathrm{O}$ & 0 & 0 & 0 & 0 & 0 \\
\hline
\end{tabular}




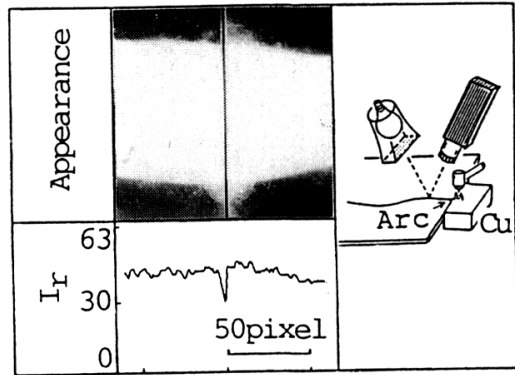

Fig.11 Effect of arc on recognition of weld line

一となる.これに対し，反射照明では以上の問題が生 じないので，ステンレス鋼板の溶接線認識には適して いる. SPCC鋼板では，側方照明によると溶接線が輝く 場合があり認識が困難であったが, 前方照明及び反射 照明によれば安定して溶接線の認識が可能であった。

\section{3 認識に及ぼすアーク光の影響}

溶接のインプロセス制御では、視覚センサの近傍に アーク光源が存在しており,これが溶接線の認識を妨 げる場合がある。そこで，溶接線の認識に及涩すアー ク光の影響について検討を加えた. 図11は，その結果 を示したもので，矩形の反射照明による溶接線近傍の 外観写真と輝度分布を示したものである。アークには ArシールドのTIG アークを用いた．陰極にタングステ ン電極を，陽極に銅ブロックを用い, アーク長 $2 \mathrm{~mm}$, 溶接電流15A として実験を行った。図には示していな いが、側方及び前方照明ではカメラが下方を向いてい るのでアークの反射光が一部カメラの視野に入り，ま たエッジか輝いて安定した認識が困難な場合があった. これに対し，図に示すように反射照明では，比較的安 定して溶接線を認識できた。この理由として，カメラ がアークに対して逆方向に $15^{\circ}\left(\beta=75^{\circ}\right)$ 傾けて設置 されておりアーク光が視野内に入り難いこと，また照 明用の光源を直接背景に見ているためアークの反射光 の影響を受けにくいことなどが考えられる.

\section{4. アーク長制御}

一般に, アーク溶接におけるアークの長さ (アーク

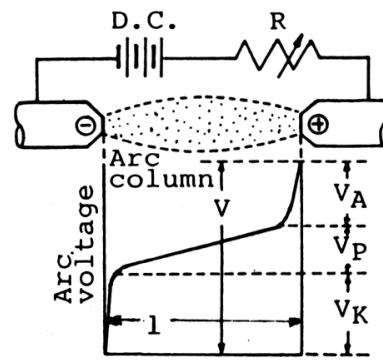

Fig.12 Voltage distribution of arc

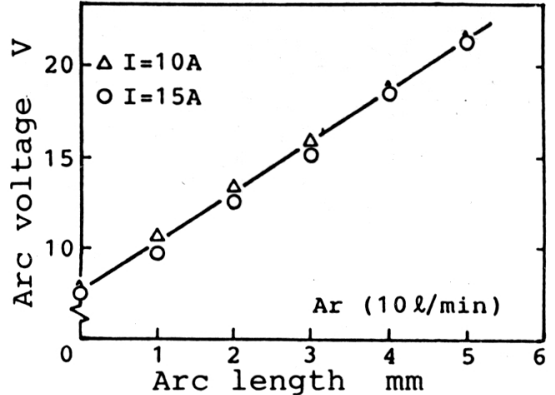

Fig.13 Relation between arc length and voltage

長） 1 は，被溶接材の溶け込み状態に著しい影響を持 つことが知られている，とくに，薄板溶接において良 好な溶接結果を得るためには，溶接電流，溶接速度は 勿論アーク長を適正に維持する必要がある。 そこで， アーク電圧を利用したアーク長制御を試みた。

図12は溶接アークの電圧分布を模式的に示したもの で,ア一ク電圧 $\mathrm{V} は$ ，陰極降下 $V_{K}$ ，陽極降下 $V_{A}$ 及 びアーク柱降下 $V_{p}$ の和で表わされる。.すなわち,

$$
\mathrm{V}=\mathrm{V}_{\mathrm{K}}+\mathrm{V}_{\mathrm{A}}+\mathrm{V}_{\mathrm{P}}
$$

$\mathrm{V}_{\mathrm{K}}+\mathrm{V}_{\mathrm{A}}$ は，溶接条件が同一であればほほ一定の值 を示す。またアーク長1が極端に短い場合を除けば， $\mathrm{V}_{\mathrm{P}}$ は 1 にほぼ比例し, 電流がほぼ同一であ九ば比例 定数（アーク電位傾度） $\mathrm{g}$ は一定の値を示す。いま， $\mathrm{V}_{\mathrm{K}}+\mathrm{V}_{\mathrm{A}}$ を $\mathrm{a}$ と置くと, 式(1)は

$$
\mathrm{V}=\mathrm{a}+\mathrm{g} \cdot \mathrm{l}
$$

と書き換えることができる，したがって，アーク長 1 はVを制御することにより制御できることがわかる.

図13は，一例として溶接電流を10A及び15Aとした場 合のアーク長 1 とアーク電圧 $V$ との関係を示したもの である. 図より，1の増加と共に V は概略直線的に增 大しており、式(2) が成立していることがわかる、そ こで，この関係を用いてアーク長の制御を行った。

図14は，アーク長の制御を目的とするZ軸制御の流 れ困である.まず，電極先端と母材を接触させ，アー ク発生に必要な電流を通電する. 通電直後に, トーチ を引き上げて電極先端と母材との接触を断つことによ クアークを発生させる．アーク電流を所定の電流值に 調節した後, 直ちにアーク電圧 $V$ を取り込み, あらか じめ設定しておいた目標電圧 $V_{\text {a }}$ と比較する. 電圧 $\mathrm{V}$ がV。より低い場合にはパルスモー夕に信号を出力し てトーチを上开させ，逆にそれより高い場合にはトー 一チを下降させる.この動作を所定の周期(約 $0.16 \mathrm{~s}$ ) で絽り返すことによって一定のアーク長を保つ.

図15は，母材を溶接進行方向に $10^{\circ}$ 傾斜させて設置 し, 溶接を行った場合の電圧変動を示すオシログラム である. 制御を行わない(a) では, 溶接の進行と共に アーク長か増大し, 電圧は上昇して遂にはアークの維 持が困難となる．これに対し，制御を行った (b) では， 


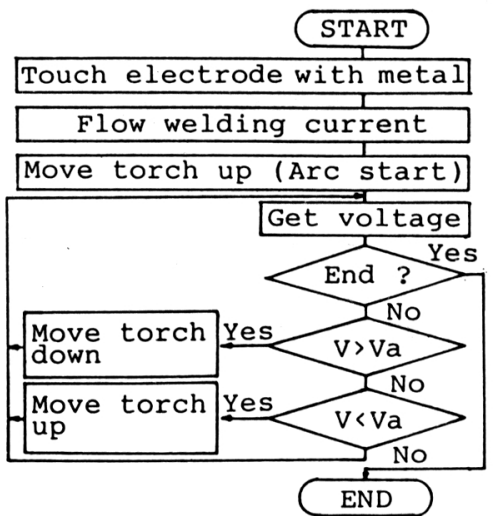

Fig.14 Flow chart of $\mathrm{Z}$-axial control

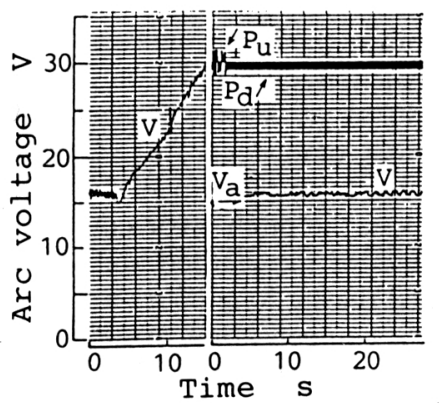

(a) No control (b) Control

Fig.15 Effect of $z$-axial control on
arc voltage $\left(\alpha=10^{\circ}\right)$

$\mathrm{V}$ は目標電圧 $15 \mathrm{~V}$ におおむね保持されており，この結 果より，傾斜角が約 $10^{\circ}$ までであれば, 本システムに よりアーク長制御が可能であることが確認される.

\section{5. 溶接実験結果}

本制御システムを用い，インプロセスで板厚 $0.5 \mathrm{~mm}$ のステンレス鋼板を突合せ溶接した場合のビードの外 観を図16に示す，溶接には T I G 溶接法を用い,アー ク長 $2 \mathrm{~mm}$, 溶接電流 $15 \mathrm{~A}$, 溶接速度 $20 \mathrm{~cm} / \mathrm{min}$ 溶接条 件で行っている.なお, 溶接線は, ロボットのY軸に 対して水平方向に $\phi=5^{\circ}$, 垂直方向に $\alpha=5^{\circ}$ 傾けて ある. 写真より良好な溶接結果が得られており，これ より，視覚センサによる溶接線追従制御及び電圧セン サによるアーク長制御を用いて，薄板の自動溶接が可 能であることが確認された。

なお, 本システムはパーソナルコンピュータ等を用 いた基礎的なシステム構成であり、必ずしも満足な性 能を有してはいないが, より高性能の機器を組み合わ せれば，同様なシステムで，より高速・高精度の制御 が可能であるものと考えている.

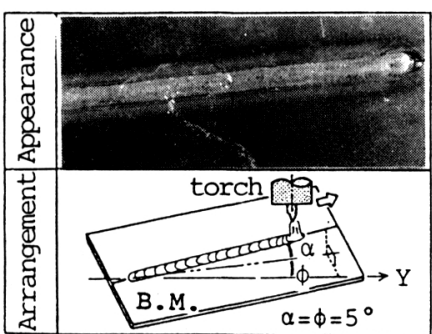

Fig.16 Welding result

6. 結言

パーソナルコンピュータを用いた基礎的なアーク溶 接ロボットシステムを構築した.これを用いて、薄板 突合せ部の溶接線の認識及び追従制御並びにアーク長 制御を行いその有効性を示した.また、溶接線認識に 及ぼす照明、アーク光の影響についても検討した。

得られた主な結果は，以下のようにまとめられる.

（1）照明方法として，側方照明，前方照明に加えて反 射照明法を新たに提案し，その有効性を示した。

(2) 本研究で構築した基礎的な溶接線追従制御システ ムによると、約 $0.5 \mathrm{~s}$ の周期で制御が行える. その追 従精度は、溶接線の傾き角度が $20^{\circ}$ で約 $\pm 0.4 \mathrm{~mm}$ で ある。

(3) 電圧センサによるアーク長制御システムの有効性 が確認された．溶接線の傾斜が $10^{\circ}$ の場合の追従誤 差は約 $1 \mathrm{~V}$ である。

（4）傾斜した溶接材料の溶接実験の結果, 本システム による溶接線追従制御及びアーク長制御の自動溶接 に対する有効性が確認された。

最後に, 本研究にご協力頂いた研究当時慶応義塾大 学理工学部学生の後藤泰久君及び斉藤道玄君（いずれ も現在，侏日本アイ・ビー・エム）に深甚なる謝意を 表する。

$$
\text { 参 考 文 献 }
$$

1) 井上勝敬 : 溶接プロセスのオンライン検出のため の画像処理（第 1 報），溶接学会誌, 49.9 (1980) 609.

2 ) 仲田周次, 黄 杰, 活羽康夫, 小走利男, 牧野吉 延：レーザ反射・散乱光強度分布に基づく開先情 報の検出法とその検出アルゴリズム, 溶接学会論 文集, 7,1(1989) 82 .

3 ) 杉谷祐司, 西泰彦: 溶込み深さの最適制御方法に 関する基礎的検討，溶接学会論文集，7,1 (1989) 15.

4 ) 窪田武文, 大嶋健司, 陳建中：画像処理計測によ る G M A 溶接のトーチ位置およびアーク長のサン プル値制御, 電気学会論文集D. 107.4(1987) 456 .

5 ) 仲田周次, 黄 杰: 溶接プロセス制御用視覚シス テムの棈築とその溶接線検出・自動追尾への応用, 溶接学会論文集, 7.4(1989) 467 . 